\title{
Biochar Effects on Weed Management ${ }^{1}$
}

\author{
Neeta Soni, Jason A. Ferrell, Pratap Devkota, and Michael J. Mulvaney ${ }^{2}$
}

\section{Target Audience}

This publication is intended to provide UF/IFAS Extension specialists, county agents, commercial growers, land managers, and gardeners with an overview of the impact of biochar use as a soil amendment on weed management.

\section{Introduction}

Biochar is a carbonaceous material produced by a method called pyrolysis. This method consists of the combustion of plant residue under high-temperature and low-oxygen conditions. As a result, oil, gas, and biochar (a type of charcoal) are generated, which can be used as energy sources. Biochar characteristics change depending on the feedstock used and the temperature of pyrolysis. Although biochar can be burned as common charcoal, it can also be used as a soil amendment. In the soil, biochar acts like a sponge, retaining water and nutrients for plant uptake that could benefit crop growth. Biochar decomposition in the soil occurs very slowly, which means that chemical and physical properties of this material can last for long periods of time. In addition, biochar binds pollutants or industrial wastes in the soil, reducing their risk of reaching groundwater and mitigating their potential negative impact on the environment.

\section{Biochar Effect on Weed Control}

Biochar can potentially improve conditions in the soil for plant growth. Research has shown that weed species exhibit minimal changes in germination and emergence patterns with the addition of biochar. Regardless, it is important to monitor changes in weed populations after biochar application. This is important because biochar can decrease herbicide efficacy. Preemergence herbicides are applied prior to crop emergence. These herbicides are sprayed directly on the soil to ensure that weed seedlings come into contact with the herbicide. The efficacy of preemergence herbicides can be affected by adsorption by soil organic matter, and degradation by microorganisms, light, and temperature. When herbicide adsorption occurs, the active molecule is bound to the biochar (particles or organic matter) and is not available for plant uptake.

Experiments were conducted at four locations in west Florida with soils of different textures and organic matter (SOM) content (Table 1). The effect of biochar incorporation into the soil (Figure 1) and its effect on the activity of atrazine and pendimethalin - two widely used preemergence herbicides in crops such as corn, sugarcane, cotton, and peanut-were evaluated. The biochar used was rich in carbon and had low levels of nutrients such as nitrogen, calcium, and magnesium (Table 2). After herbicide application, weed populations were monitored for four weeks.

1. This document is SS-AGR-386, one of a series of the Agronomy Department, UF/IFAS Extension. Original publication date March 2015. Revised May 2021. Visit the EDIS website at https://edis.ifas.ufl.edu for the currently supported version of this publication.

2. Neeta Soni, former graduate student, UF/IFAS West Florida Research and Education Center; Jason A. Ferrell, professor, weed science and invasive plants, Agronomy Department, and director, UF/IFAS Center for Aquatic and Invasive Plants; Pratap Devkota, assistant professor, weed science, UF/ IFAS WFREC; and Michael J. Mulvaney, assistant professor and cropping systems specialist, Agronomy Department, UF/IFAS WFREC; UF/IFAS Extension, Gainesville, FL 32611. Originally written by Neeta Soni; revised by Pratap Devkota.

All chemicals should be used in accordance with directions on the manufacturer's label.

The Institute of Food and Agricultural Sciences (IFAS) is an Equal Opportunity Institution authorized to provide research, educational information and other services

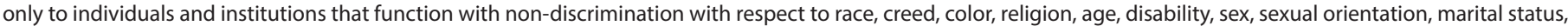
national origin, political opinions or affiliations. For more information on obtaining other UF/IFAS Extension publications, contact your county's UF/IFAS Extension office. U.S. Department of Agriculture, UF/IFAS Extension Service, University of Florida, IFAS, Florida A \& M University Cooperative Extension Program, and Boards of County Commissioners Cooperating. Nick T. Place, dean for UF/IFAS Extension. 


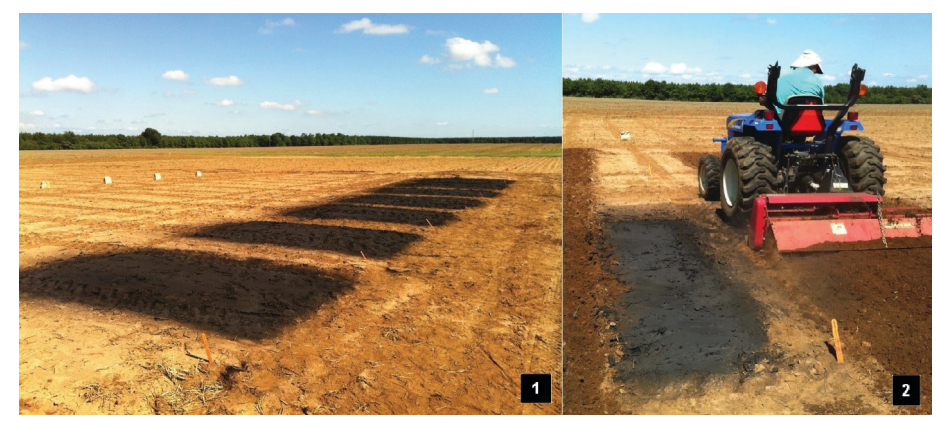

Figure 1. (1) Biochar application at 2 ton/acre and (2) incorporation prior to row-crop production (e.g., corn, cotton, peanut, soybean). Credits: Neeta Soni, UF/IFAS

Regardless of soil type, it was observed that herbicides provided no weed control where biochar was applied at 2 ton/A (Figure 2). Doubling the label rate of herbicide did not compensate for the loss of weed control due to biochar incorporation. This is attributed to tight biochar adsorption of the herbicide, which renders the herbicide unavailable for uptake by emerging weeds. Biochar incorporation effectively increases SOM content in the soil, thus enhancing herbicide adsorption. Biochar characteristics are similar to those of activated carbon, which is sometimes applied in rows to protect crops from herbicide injury.

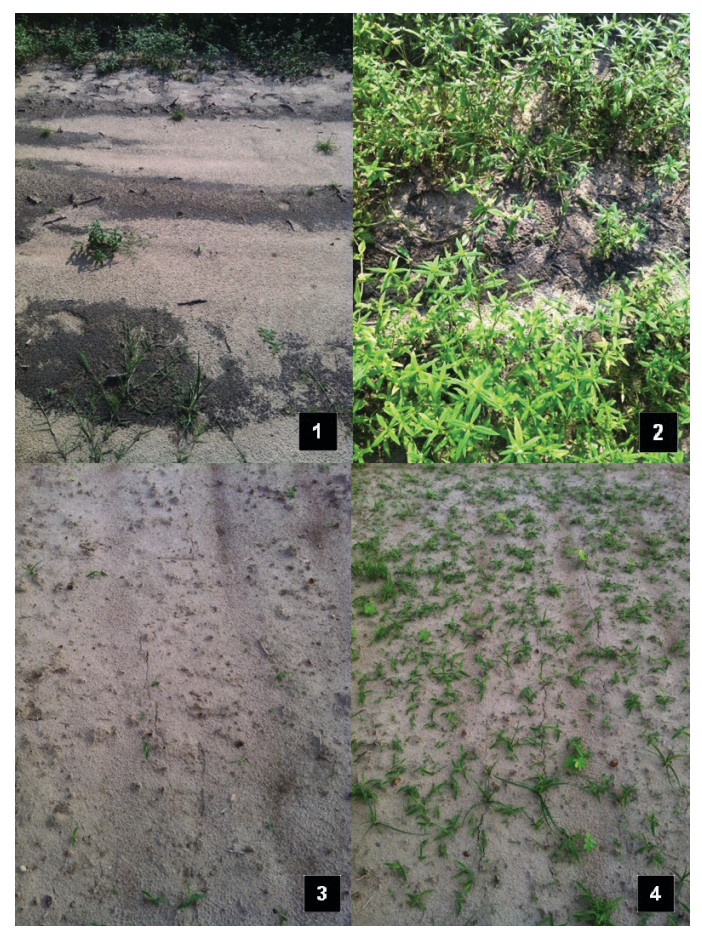

Figure 2. Atrazine at $8 \mathrm{pt} / \mathrm{acre}$ (label rate $=4 \mathrm{pt} / \mathrm{ac}$ ): 1 ) without biochar; 2) with biochar at 2 ton/ac. Pendimethalin at $4 \mathrm{pt} / \mathrm{ac}$ (label rate $=2 \mathrm{pt} /$ ac); 3) without biochar; 4) with biochar at 2 ton/ac.

Credits: Neeta Soni, UF/IFAS

\section{Practical Considerations for Biochar Use}

Growers considering use of biochar as a soil amendment on their farms or gardens should be aware that preemergence herbicides may not provide acceptable levels of weed control. Residual herbicides may not provide good weed control regardless of soil type after biochar application. This does not necessarily mean that biochar should be avoided. Instead, it means that when biochar has been applied to the soil, management practices need to be adjusted to obtain adequate weed control. If the herbicide label allows, preemergence herbicide rates could be increased based on organic matter content to levels similar to those used on muck soils. However, many herbicide labels do not have information for use on muck soils and do not provide information to compensate for biochar reduction of herbicidal activity. Therefore, alternative weed control practices should be considered. For example, preemergence herbicides maybe replaced by early and frequent cultivation to mechanically remove weeds. In small areas and areas where the risk of mechanical injury to the crop or to desirable plants is high, hand weeding might be the safest way to compensate for the lack of preemergence herbicide control. Another alternative may include weed management strategies that rely on the use of postemergence herbicides. This alternative requires the use of postemergence herbicides and rates that are safe to the crop and desirable plants but also provide effective weed control. For postemergence herbicides as well as mechanical weed control, timing and weed size are critical. As a rule of thumb, postemergence herbicide applications and cultivation should be used when weeds are no more than 3 inches in height or diameter. A well-designed weed control strategy that accounts for reduced preemergence herbicide activity will help maximize the benefits of using biochar for crop production. 
Table 1. Soil type, texture, SOM content, and pH of field experiment sites prior to biochar addition.

\begin{tabular}{|c|c|c|c|c|c|}
\hline Soil Types & Sand & Clay & Silt & SOM & pH \\
\hline & \multicolumn{4}{|c|}{--------------------(\%)------------------ } & \\
\hline Dothan sandy loam & 36 & 30 & 34 & 2.3 & 6.5 \\
\hline Lakeland sandy loam & 70 & 18 & 12 & 2.0 & 6.2 \\
\hline Angie variant clay & 42 & 28 & 30 & 0.8 & 6.7 \\
\hline Fuquay sand & 68 & 26 & 6 & 2.5 & 6.1 \\
\hline
\end{tabular}

Table 2. Characteristics of biochar used in the study. Biochar was produced from pine wood chips by pyrolysis at $800^{\circ} \mathrm{C}$.

\begin{tabular}{|l|c|}
\hline \multicolumn{1}{|c|}{ Characteristic $^{\mathrm{a}}$} & Value \\
\hline $\mathrm{pH}$ & 9.2 \\
\hline $\mathrm{EC}\left(\mu \mathrm{S} \mathrm{cm}^{-1}\right)$ & 1775 \\
\hline Nitrogen (\%) & 0.53 \\
\hline Carbon (\%) & 62.5 \\
\hline $\mathrm{P}_{2} \mathrm{O}_{5}(\%)$ & 0.41 \\
\hline $\mathrm{K}_{2} \mathrm{O}(\%)$ & 0.19 \\
\hline Sulfur (\%) & 0.12 \\
\hline Boron (\%) & 0.008 \\
\hline Calcium (\%) & 1.96 \\
\hline Magnesium (\%) & 0.49 \\
\hline Zinc (ppm) & 2400 \\
\hline Manganese (ppm) & 200 \\
\hline Iron (ppm) & 1500 \\
\hline a Values were determined in aqueous solution. Concentrations are based on samples with 2\% moisture content.
\end{tabular}

